\title{
Effects of Job Stress on Employees Job Performance A Study on Banking Sector of Pakistan
}

\author{
Ashfaq Ahmed, Dr. Muhammad Ramzan \\ ${ }^{I}$ The Superior College, Gulberg 3, Kalama Chowk, Lahore, Pakistan. \\ ${ }^{2}$ Director Libraries, Lahore University of Management Sciences (LUMS) Lahore, Pakistan.
}

\begin{abstract}
Currently Bankers are under a great transaction of stress and due to many backgrounds of stress such as Excess, Role doubt, Role conflict, Concern for people, Contribution, Lack of feedback, possession up with rapid technologicalchange. Being in an inventive role, Career development, Organizational structure and climate, and recent episodic events. The thing which find out is stress. This study examines the relationship between job stress and job performance on bank employees of banking sector in Pakistan. The study examines the purpose model in relation of job stress and its impact on job performance by using sample of 144 participants. In participant the data ofsenior, graduate employees including customer services officers and managers of well reputed rising bank in Pakistan. The data were obtained through close ended questionnaire. A statistical test of regression, correlation and reliabilities were also confirmed. The results are significant with negative correlation between job stress and job performances and shows that job stress significantly reduces the performance of an individual. The results suggest to the organization that they have sustained a very health, cooperative and friendly environment within the team for better performance.
\end{abstract}

Keywords: Job performance, Job stress, Effects of stress

\section{Introduction}

Over the past few decades stress is emerging as an increasing problem in organizations. Stress is vigorous state in which a person is confronted with an opportunity, demand, or resource related to what the individual wishes and for which the outcome is perceived to be both vague and vital. (Selye, 1936) first introduced the idea of stress in to the life science. He defined stress as the force, pressure, or tensionsubjected upon an individual who resists these forces and attempt to uphold its true state. Basically what is stress? The HSE (HealthSafety Executive Uk) defines stress is an undesirable response people have to tremendous pressures or other types of demands placed upon them. It arises when they worry they cannot deal with. Some stress can be good, and some can be bad. HSE distinguishes between stress and pressure. Pressure is seen as positive and something that actually helps improve our performance. We all need a certain amountof pressure to perform well - ask anyathlete, actor or actress. However, the problems arise when the sources of pressure become too frequent without time to recover, or when just one source of pressure is too great for us to cope with. Stress can be understood more comprehensively as, it is a condition which happens when one realizes the pressures on them, or the requirements of a situation, are wider than their recognition that they can handle. If these requirements are huge and continue for a longer period of time without any interval, mental, physical or behavioral problems may occur, (Health \&Safety Executive UK). Stress has a positive effect on employees of any organization but up to a certain extent up to which an employee can cope with it, mostly it exceeds the bearable limits and has a negative result on employees. This is the base of the research study which has not yet been conducted in Pakistan. A lot of work has been conductedoutside Pakistan. Number of studies has been conducted in different area of world but a huge gap exists in third world countries like Pakistan. The purpose of this study is to examine stress in employees of banking sector of Pakistan

\section{Review of Literature}

Stress is an unwanted reaction people have to severe pressures or other types of demands placed upon them. A huge and multi fields literature points a lot of key factors such as work environment, management support, work load etc. in determining the stressful the work can be and its effect on employee physical and mental health, (Ganster\&Loghan, 2005). According to (Anderson, 2002) work to family conflicts is also a predecessor which creates stress in employees of an organization. Job stress has been also viewed as dysfunctional for organizations and their members (Kahn, Wolfe, Quinn, Snoek, \& Rosenthal, 1964). Although stress has been variously viewed as an environmental stimulus to an individual (Kahn et al., 1964) Selye, 1956 defined stress as an individual's reaction to an environmental force that effect an individual performance. Job related stress can be mostly immobilizing because of its possible threats to family functioning and individual performance. Job related stress can create an difference between demands on families and the ability of families to provide material security for them (McCubbin\&Figley, 1983). While there is a significant body of 
researchwhich deals with work and family there is relatively little research (e.g., Jacobson, 1987) which deals specifically with perceived job insecurity (i.e., concerns or fears about job loss) and marriage and family life (e.g., Buss \&Redburn, 1983). Stress condition which happens when one realizes the pressures on them, or the requirements of a situation, are wider than theirrecognition that they can handle, if these requirements are huge and continue for a longer period of time with outany interval, mental, physical or behavior problems may occur, (Health \&Safety Executive UK). Stress exists in every organization either big or small the work places and organizations have become so much complex due to which it exists, work place stress has significant effects over the employees job performance, and the organizations in Uk are trying to cope with this scenario, (R. Anderson, 2003). Eleven forces are used as an antecedents of stress by researches (Overload, Role vagueness, Role conflict, Responsibility for people, Participation, Lack of feedback, Keeping up with quick technological change, Being in an innovative role, Career growth, Organizational structure and environment, and Recent episodic events.,) Overload :excessive work or work that is outside one's capability(Franch and Caplan ,1972; Margolis et al, 1974 ; Russek and Zohman, 1958) Role Ambiguity : Role insufficient information concerning powers, authority and duties to perform one's role (French and Caplan, 1972; Kahn, et al, 1964 ), Role Conflict: Supervisors or subordinates place contradictory demands on the individual(Beehr et al, 1976; Caplan and Jones, 1975; Caplan, etal, 1975; Hall and Gordon, 1973; Kahn et al, 1964) Responsibility for people: Responsibility for people, well-being works, job security, and professional development (French and Caplan, 1972; Pincherle, 1972) Participation: Extent to which one has influence over decisions relevant to one's job (Kasl, 1973) Margolis et al, 1974). Lack of Feedback: Lack of information about job performance (Adams, 1980 Cassel, 1974) Keeping up with rapid technological change: Keeping up with rapid changes in the information processing field (Ginzburg, 1967) Being in an innovative role: Having to bring about change in the organization (Kahn, et al.1964) Lawrence and Lorsch 1970. Career development: Impact of status dissimilarity, lack of job security, let down ambition (Brook 1973) Erikson and Gunderson 1972; Kahn, et al. 1964) Recent episodic events: Certain life events, such as divorce and bereavement, that are highly stressful (Adams 1980; Cobb, 1977 Holmes and Rahe 1975). (Rose, 2003) In every organization and at every levelof management and workers an elevated average level of stress is to be found which mostly has an effect on employee's job satisfaction.

According to (Rose,2003) employees have tendency towards highlevel of stress regarding time, working for longer hours which reduces employees urge for performing better. Management support helps in reducing or increases stress in employees, (Stamper \&Johlke, 2003) apparent organizational assistance, management support work as a cushion which acts positively in decreasing work related stress in employees. There are a lot of reasons causing stress work familyconflicts work over load one of reason inidentified by (Stamper \&Johlke,2003) that if the organization or management does not appreciates its employees for their hard work or contribution toward the organization creates stress and mostly creates intention toleave.

(Ivancevich\& Donnelly, 1975) studied the link between anxiety stress with satisfaction and performance ofemployees, that lower anxiety stress improves performance of employee's which he studied in different managerial level of an organization. (Beehr, Jex, Stacy \& Murray, 2000) found the relationship between occupational stressors an the performance of employees of an organization as well as it can affect the employees psychologically. (Jamal, 1984) studied a association between job stress and job performance between managers and blue-collar employees. Stress on job can be stated as the outcome of an individual due to the working environment from which he feels unsecured. Differentrelationships are projected between job stress and performance: U-shaped and curvilinear, positive linear, negative linear and no relationship between the stress and performance. A random sample of 305 blue-collar and 325 managerial workers in Canadian firm are surveyed through structured questionnaire. Variables used for this studywere job stress, job performance, and organizational commitment. A negative linear relationship between job stress and job performance was found. Very limited evidence is seen for curvilinear or no association.

Numerous studies found that fob stress influences the employees' job satisfaction and their overall performance in their work. Because most of the organizations now are more demanding for the better job outcomes. In fact, modern times have been called as the "age of anxiety and stress" (Coleman, 1976). The stress itself will be affected by number of stressors. Nevertheless, Beehr and Newman (1978) had defined stress as a situation which will force a person to deviate from normal functioning due to the change (i.e. disrupt or enhance) in his/her psychological and/or physiological condition, such that the person is forced to deviate from normal functioning. From the definition that has been identified by researchers, we can conclude that it is truly important for an individual to recognize the stresses that are facing by them in their career. Some demographic factor may influence the way a university academic staff act in their workplace.

Management role of an organization is one of the aspects that affect work-related stress among workers (Alexandros-Stamatios et. al., 2003).Workers in an organization can face occupational stress through the role stress that the management gave. Role stress means anything about an organizational role that produces adverse consequences for the individual (Kahn and Quinn, 1970). Management will have their own role thatstands as 
their related. Role related are concerned with how individuals perceive the expectations other have of them and includes role ambiguity and role conflict (Alexandros-Stamatios et. al., 2003).

Family and work are inter-related and interdependent to the extent that experiences in one area affect the quality of life in the other (Sarantakos, 1996). Home-work interface can be known as the overlap between work and home; the two way relationship involves the source of stress at work affecting home life and vice versa effects of seafaring on home life, demands from work at home, no support from home, absent of stability in home life. It asks about whether home problems are brought to work and work has a negative impact on homelife (Alexandros-Stamatios G.A et al., 2003). For example, it questions whether the workers have to take work home, or inability to forget about work when the individual is at home. Home-work interface is important for the workers to reduce the levelof work-related stress. According toLasky (1995) demands associated with family and finances can bea major source of 'extra-organisational' stress thatcan complicate, or even precipitate, work-place stress. Russo \&Vitaliano (1995) argued that the occurrence of stressors in the workplace either immediately following a period of chronic stress at home, or in conjunction with other major life stressors, is likely to havea marked impact on outcome.

Several studies have highlighted the deleterious consequences of high workloads or work overload. According to Wilkes et al. (1998) work overloads and time constraints were significant contributors to work stress among community nurses. Workload stress can be defined as reluctance tocome to work and a feeling of constant pressure(i.e. no effort is enough) accompanied by the general physiological, psychological, and behavioral stress symptoms (Division ofHuman Resource, 2000). Al-Aameri AS. (2003) has mentioned in his studies thatone of the six factors of occupational stress is pressure originating from workload. AlexandrosStamatios G.A. et al. (2003) also argued that "factors intrinsic to the job" means explore workload, variety of tasks and rates of pay.

Rapidly changing global scene is increasing the pressure of workforce to perform maximum output and enhance competitiveness. Indeed, to perform better to their job, there is a requirement for workers to perform multiple tasks in the workplace to keep abreast of changing technologies (Cascio, 1995; Quick, 1997). The ultimate results of this pressure have been found to one of the important factors influencing job stress intheir work (Cahn et al., 2000). A study in UK indicated that the majority of the workers were unhappy with the current culture where they were required to work extended hours and cope with large workloads while simultaneously meeting production targets anddeadlines (Townley, 2000).

Role ambiguity is another aspect that affects job stress in the workplace. According to Beehr et al. (1976), Cordes\& Dougherty (1993), Cooper (1991), Dyer \&Quine (1998) and Ursprung (1986) role ambibuity exists when an individual lacks information about the requirements of his or her role, how those role requirements are to be met, and the evaluative procedures available to ensure that therole is being performed successfully. Jackson \& Schuler (1985) and Muchinsky (1997) studies found role ambiguity to lead to such negative outcomes as reduces confidence, a sense of hopelessness, anxiety, and depression.

\section{Stress models}

Following the brief review on motivation, the emphasis now shifts to the all-important issue of stress employees may experience atwork.Selye (1956), as cited in Le Fevre et al. (2003), first introduced the term 'stress' to describe physical and psychological responses to severe conditions or influences. He used the word 'stress' which is an engineering term, to describe the responses to a force that when is implemented in bodies, causes deformation. While there is an agreement among researchers on the stress related terminology adopted (Maslach, 1998), Cummings and Cooper (1998) point out the difficulty to develop a coherent theory on stress, as different disciplines (medicine, psychology, sociology, management) and research methodologies have looked into this area. Nevertheless, a constellation of key stress related conceptualizations are presented in Table 2 below. Stress can be defined as "the non-specific response of the body to any demand placed upon it" (Selye, 1987, p.17). Selye (1956) used also the term 'stressor' to describe the force that when acting to a body, creates stress. Le Fevre et al. (2003) maintains that the term 'stress' describes a force that causes deformation, while the notion of response is better described by the term 'strain' referring to the manifestation of stress in a body. Selye (1964) also, used the term eustress (or good stress); while eustress and distress are regarded as being distinct elements of total stress, it is only the individual who can perceive stress as eustress or distress, according to whether one perceives the demand stimulus aspleasant or not (Selye, 1987). Having acknowledged that employers would rather maintain an amount of pressure or stress at "optimal" levels to boost employee performance (Certo, 2003), it is not easy to maintain a fine line between stress levels, motivation and one's wellbeing. Internal competition may for example, exert an amount of pressure or stress that at times can act as a motivator. In this respect, Papasolomou-Doukakis et al. (2004) suggest that a competitive internal environment can motivate staff to improve performance; such competition among a firm's salesmen is facilitated by focusing on the achievement of sales targets, linking the achievement of sales targets to monetary rewards and using league tables involving sales performance. Too much pressure however, may have stress related implications 
such as employee mental alienation and/or impact onindividual performance (Sdrolias et al, 2005); also, destruction of team spirit, dissatisfaction with or absence or even resignation from work can be manifestations of workstress (McCarty et al, 2007; Strahan et al, 2008). Moreover, occupational stress may cause a loss of talent and an increase of training cost, due to high turnover (Cartwright and Boyes, 2000). While stress is inevitable, it constitutes a real threat tothe quality of life for employees (Dyck, 2001) not to mention its link to an increased risk of morbidity and mortality (Siegrist, 1998). Also (and related to the above), it is the widely studied effect called 'burnout'. The term burnout syndrome was first introduced in the 1970s and defined as a response to chronic work stress (Freudenberger, 1974). It is a three-dimensional syndrome involving emotional exhaustion, depersonalization and decreased personal accomplishment (Byrne, 1993) dimensions that do not necessarily appear in the same order (e.g. see Golembiewski et al., 1986; Leiter and Maslach, 1988).

\begin{tabular}{|c|c|}
\hline \multicolumn{2}{|l|}{ Stress Models } \\
\hline Theory & Summary \\
\hline Role Stressors Kahn et al (1964)]. & $\begin{array}{l}\text { "Stress is defined as the result of stressors, which are, Role } \\
\text { ambiguity, Role overload and Role conflict. The bigger the } \\
\text { amount of stressors is the bigger is the stress". }\end{array}$ \\
\hline Job Demand-Control Model (DCM) Karasek (1979) & $\begin{array}{l}\text { In real, a level of stress comes when this level is used in } \\
\text { learning process". Stress on Job generates when expectations } \\
\text { are high and employees don't have full control on the job. } \\
\text { Capacity think and ability to take right decisions about how to } \\
\text { manage work to get optimal results. }\end{array}$ \\
\hline $\begin{array}{l}\text { Conservation of Resources } \\
\text { (COR) Hobfoll (1989) }\end{array}$ & $\begin{array}{l}\text { Stress is reason of causing tension which is the result of the } \\
\text { gap between what is expected and what is done. "Job } \\
\text { resources are related to: the organization's offerings, } \\
\text { interpersonal relationships, working structures and task } \\
\text { structures". }\end{array}$ \\
\hline Job characteristics Ganster and Schaubroeck (1991) & $\begin{array}{l}\text { According to Ganster and Schaubroeck (1991), "there is } \\
\text { strong indirect evidence that stressors (job characteristics) } \\
\text { affect human health. It is also assumed that there is a strong } \\
\text { relationship between working experiences and psychological } \\
\text { and emotional responses." }\end{array}$ \\
\hline $\begin{array}{l}\text { Effort Reward Imbalance (ERI) } \\
\text { Siegrist (1996) }\end{array}$ & $\begin{array}{l}\text { says that dissatisfaction with the job is the result between non- } \\
\text { equality of efforts done to complete tasks of the job and } \\
\text { incentive both intrinsic and extrinsic. }\end{array}$ \\
\hline $\begin{array}{l}\text { Person-environment P-E fit theory } \\
\text { (Edwards } \text { et al., 1998) }\end{array}$ & $\begin{array}{l}\text { According to this theory, when a person is unable to adjust in } \\
\text { the prevailing environment, then it converts oneself into a } \\
\text { stressor and results in stress. There are three realistic } \\
\text { relationships exists between stressor and stress. One is the } \\
\text { relationship between expectations and capacity, second } \\
\text { relationship of demand and supply of needs, third mixture of } \\
\text { expected capacity and supply of needs. }\end{array}$ \\
\hline $\begin{array}{l}\text { The Cybernetic theory } \\
\text { (Cummings and Cooper, 1998) }\end{array}$ & $\begin{array}{l}\text { This theory is considering that stressor and stress is as } \\
\text { sequential situation. }\end{array}$ \\
\hline Control theory (Spector, 1998) & $\begin{array}{l}\text { This theory is also tells that that person has no control over } \\
\text { work load, schedule and complete independence }\end{array}$ \\
\hline
\end{tabular}

Source: Dr. Nikos Kakkos, et.al. 2010

In light of the above, it seems there is a clear linkbetween stress and emotional reactions at an individual level. Occupational stress has been of increasing concern for employees and has also attracted employers' interest because the risk of being persecuted for damages to stressed employees has increased (Midgley, 1997). The financial effect of employees' ill health (or well-being) on employers is certainly not negligent and Harris (2000) highlights how important itis for management to appreciate that maintaining motivated and satisfied employees is likely to lead to happy and satisfied customers, too. While employers have a moral (at least) obligation to protect their employees' health and well-being by providing a healthy (and possibly non-stressful) working environment (Patterson et al., 1997), there are frameworks such as the Management Standards (Health and Safety Executive, 2009) aiming to identify, isolate and control the primary risk factors coming from six main sources of work stress: (i) Demands-workload, work patterns and work environment, (ii) Control- whether employees have a say in the way they do their work, (iii) Support- referring to the encouragement, sponsorship, resources provided by the organization, the supervisors or the colleagues, (iv) Relationships-promoting positive work to avoid conflict and unacceptable behavior, (v) Role- whether an organization ensures that employees roles do not conflict and that employees understand their roles and (vi) Change- how organizational change is managed and communicated within the organization. Having acknowledged that non-properly managed stressors can be linked to poor employee well-being, lower productivity and increased absence from work, the former management standards determine an organization's culture characteristics where key stressors are isolated so as to manage and control their stress effects on employees. 


\section{Job Performance}

Performance of an employee at his/her workplace is a point of concern for all the organizations irrespective of all the factors and conditions. Consequently the employees are considered to be very important asset for their organizations. (Qureshi\&Ramay. 2006) A good performance of the employees of an organization leads towards a good organizational performance thus ultimately making an organization more successful and effective and the vice versa. (Armstrong \& Baron, 1998). These moderators were further investigated and strong correlations between organizational commitment and work behavior were found against self reported and for supervisory report of performance. The problems arise for the organizations when they start perceiving that their organizations are already performing at their level best and with great efficiency furthermore, there is no need for further improvement in their organizations (Summers \& Hyman, 2005). Hence keeping in view these barriers must be tackled and addressed as they result in underdeveloped competencies and more over lead towards, finally the organizational ineffectiveness. Ultimate success or failure of an organization is determined majorly by the performance of their employees. (Bartlett \&Ghoshal, 1995).

\section{Theoretical Framework \& Methodology}

The present study was conducted among employees of a well reputed growing bank in Pakistan who has three categories under which employees fall those are FTE (Fixed Tenure Employees) bank contract and third party contract employees. The data was collected by means of a structured questionnaire with the help of supervisors and managers, copies of the questionnaire were given to respondents by hand. As the study is pointed towards employee stress and job performance, target sample source is well reputed growing bank in Pakistan, due to time and budget limitations convenient sampling technique is used to explore the relationship between stress and job performance of employees, my sample size is 144.The majority of respondents were male $(87 \%)$ and married (79\%). The average respondent was 39 years of age, having graduate and postgraduate qualifications.

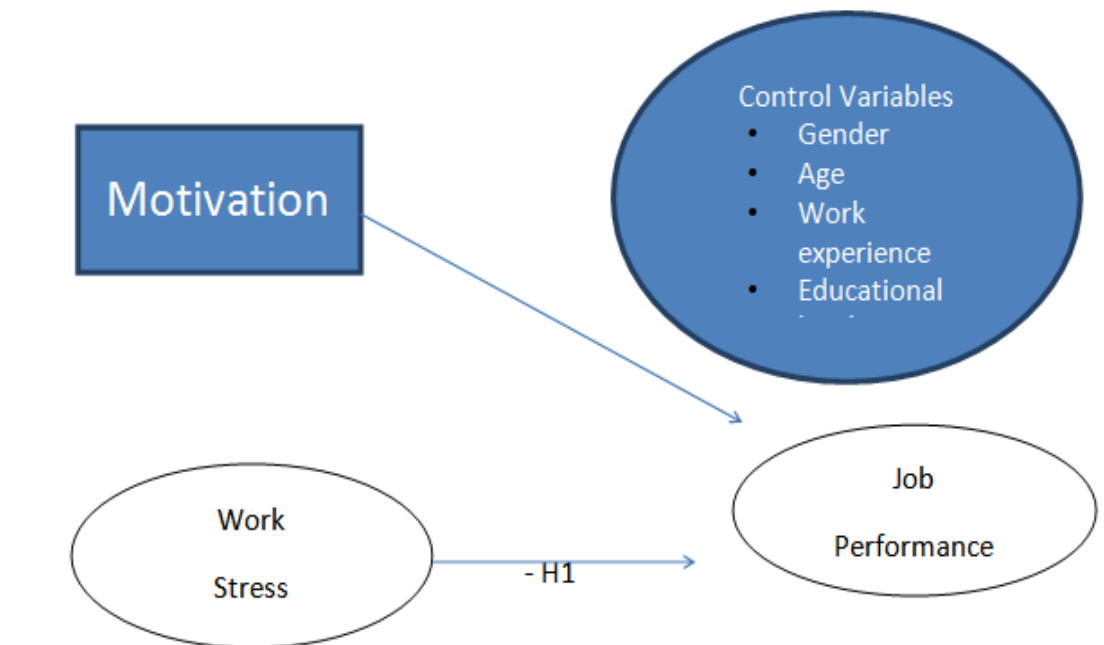

HYPOTHESIS:Job stress is negatively associated to job performance of employees Source: Dr. Nikos Kakkos, et.al. 2010

\subsubsection{Description}

Four stressors work conflicts, resource inadequacy, work overload and work ambiguity this measure was designed by Khan, Wolfe, Quinn, and Snoek (1964). It described employee perception of job stress using 15 items asking about the incidence of stressful occurrences and the degree of role burden. This scale evaluate psychological indications of stress, such as feeling of overburdened with work, not having the adequate resources and tools tocomplete given tasks or projects, and usually being incapable to handle all of the work. In many studies, the items have been used to form subscales for roleuncertainty, role overload, and resources insufficiency (Jamal, 1990; Shirom\& Mayer, 1993). The scale is rated on five likert scale form 1=strongly disagree to $5=$ strongly agree.

\subsubsection{Validity}

Job-related tension linked positively with troubles at work, work participation, work expectations, lack of mental support from a mentor, and family exception (Abraham \& Hansson, 1996; Duxbury \& Higgins, 1991: Seibert,1999). Job tension linked negatively with quality of work life, job satisfaction, goal 
accomplishment,organizational commitment, self-esteem at work, quality of family life, and life satisfaction (Abraham \& Hansson, 1996; Duxbury \& Higgins, 1991; Seibert, 1991). In Jamal (1990), the job tension subscales for role ambiguity, role overload, and resource inadequacy all correlated positively with psychosomatic problems. All the subscales except role overload correlated negatively with jobsatisfaction. In Shirom and Mayer (1993), role overload correlated positively with parent teacher conflict, teacher conflict, teacher-principal conflict, role overload correlated positively with parent teacher conflict, teacher-principal conflict, and work-home conflict.

\subsection{Job Performance (In Role Behavior)}

This measure was developed by Williams and Anderson (1991). It uses 21 items to describe three types of organizational citizenship behaviors. These are behaviors directed at specific individuals (OCBI), Behaviors directed at an organization (OCBO), an employees in-role behaviors (IRB). In this paper only the in role behavior scale having five items was used as mentioned in appendix A the scale is rated on five likert scale form $1=$ strongly disagree to $5=$ strongly agree

The questionnaire was exclusively filled by the line managers and supervisors of the employees and was kept personal form the employees and no information was leaked

Tables

Table 1 (a)

Reliability Statistics of JOB STRESS

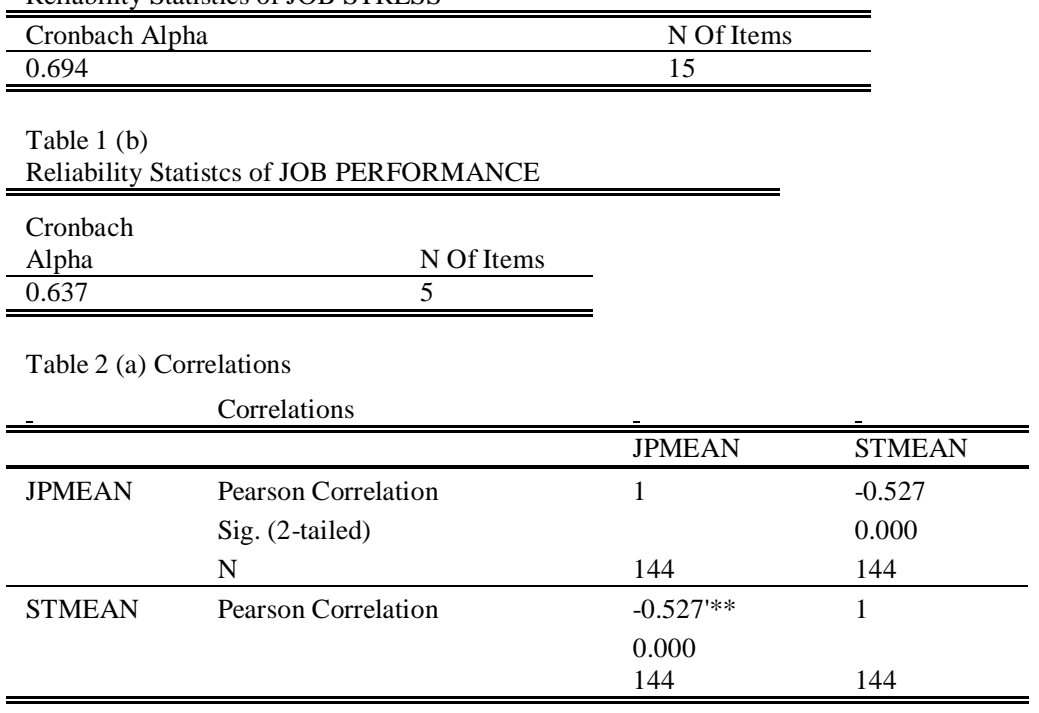

**. Correlation is significant at 0.01 level(2-tailed)

\begin{tabular}{|c|c|c|c|c|c|c|c|}
\hline \multirow[b]{2}{*}{ Model } & & \multicolumn{2}{|c|}{ Unstandardized Coefficients } & \multirow{2}{*}{$\begin{array}{l}\text { Standard } \\
\text { Coefficient } \\
\text { Beta } \\
\end{array}$} & \multirow[b]{2}{*}{$\mathrm{t}$} & \multirow[b]{2}{*}{ Sig. } & \\
\hline & & $\mathrm{B}$ & Std Error & & & & \\
\hline \multirow[t]{2}{*}{1} & (Constant & 5.477 & 0.278 & & 19.668 & 0.000 & \\
\hline & STMEAN & -0.697 & 0.094 & -0.527 & -7.390 & 0.000 & \\
\hline a. & \multicolumn{7}{|c|}{ Dependent Variable: JPMEAN } \\
\hline Table 3 & Regression & & & & & & \\
\hline Model & $\mathrm{R}$ & R Square & $\begin{array}{l}\text { Adjusted R } \\
\text { Square }\end{array}$ & $\begin{array}{l}\text { Std Error of } \\
\text { the Estimate }\end{array}$ & $\begin{array}{l}\text { R Square } \\
\text { Change }\end{array}$ & F Change & $\begin{array}{l}\text { Sig. F } \\
\text { Change }\end{array}$ \\
\hline 1 & $.527 \mathrm{a}$ & 0.278 & -0.273 & 0.47798 & 0.278 & 54.760 & 0.000 \\
\hline
\end{tabular}

\section{Results \& Discussion}

The reliabilities of both the dependent variable and independent variable are shown in table 1(a) and table (b) which are 0.694 and .637 respectively, in table the relationship between job stress and job performance is negatively correlated at significance level of P .01 that is correlation is significant. In table 2 (a) and 2 (b) as the value of beta is -.527 that shows52.7 means that for every one percent increase in job stress will have an effect of 52.7 effect on job performance which is negatively correlated to job stress. In other words 52.7 of job performance is being effected by job stress and the remaining by other factors. Regression analysis shows that relationship between job stress and job performance is proved the value of $\mathrm{R}$ square .278 it shows that the 
impact of job stress on job performance is $27.8 \%$ is explained. The purpose of this study was to find out the relationship between the job stress and job performance of employees of banking sector in Pakistan. As per hypothesis job stress had a negative relation with job performance that when stress occurs it effects the performance of employeesnegatively, (Ivancevich\& Donnelly, 1975) that lower the stress it increases the performance so both these are inversely proportional each other as to the results the correlation in table 2 shows both job stress and job performance is negatively correlated. Management support helps in reducing or increases stress in employees, (Stamper \&Johlke ,2003) apparent organizational assistance, management support work as a cushion which acts positively in decreasing work related stress in employees.(Rose, 2003) studied the results that the stress in work environment reduces the intention of employees to perform better in jobs with the increasing level of stress the employees thinking demoralize and his tendency to work well also decreases. No doubt stress is necessary for increasing performance of employees but up to a certain level. In this study the employees do their job regularly but due to workloads and time constraints their performance reduces.Banks timing is mostly from 9am to $5 \mathrm{pm}$ in Pakistan but originally there is no time limit so employees have to work for longer hours as compared to other jobs hitch isalso a reason of concern. The study was conducted only in industry that was banking sector and the impact job stress on job performance was measured only in one sector, if we want to generalize the results of this study then thisstudy should be replicated in other sectors of Pakistan as well.

\section{References}

[1]. Adams, J.D. (1980). Improving Stress Management: An Action-Research-Based OD Intervention, I Under-standing and Managing Stress: A Book of Readings. University Associates, San Diego, California, pp. 179-198.

[2]. Anderson E.S., Coffey S.B., \&Byerly T.R. (2002). Formal Organizational Initiatives and Informal Workplace Practices: Links to Work-Family Conflict and Job-Related Outcomes.Journal of Management 28,787.

[3]. Anderson R. (2003). Stress at work: the current perspective.The Journal of The Royal Society for the Promotion of Health, 123 ; 81

[4]. Beehr A. T, Jex M.S., Stacy A. B., \& Murray A.M. (2000). Work Stressors and Coworker Support as Predictors of Individual Strain and Job Performance.Journal of Organizational Behavior, Vol. 21, No. 4, pp. 391-405.

[5]. Beehr, T.A. (1976). Perceived Situational Moderators of the Relationship Between Subjective Role Ambiguity and Role Strain. Journal of Applied Psychology, Vol 61, pp. 35-40.

[6]. Brook, A. (1973). Mental Stress at Work. The Practitioner, Vol 210, pp. 500-506.

[7]. Caplan, R.D., and Jones, K.W. (1975). Effects of Work Load, Role Ambiguity, and Type A Personality on

[8]. Anxiety, Depression, and Heart Rate. Journal of Applied Psychology, Volume pp. 713-719.

[9]. Cobb, S., and Kasl, S.V. Termination. (1977). The Consequences of Job Loss, U.S. Government Printing Office.Washington, D.C.

[10]. Erickson, J., Pugh, W.M., and Gunderson, E.K.E. (1972). Status Congruency as a Predictor of Job Satisfaction and Life Stress.Journal of Applied Psychology, Vol 56, pp. 523-525.

[11]. French, J.R.P., Jr., and Caplan, R.D. (1972). Organizational Stress and Individual Strain. in A.J. Marrow,ed., The Failure of Success, AMACOM, New York, New York,

[12]. Hans S. (1936). A syndrome produced by diverse noxious agents. Nature, 138:32.

[13]. Health and Safety Executive. (2001). Help on Work-related Stress: A Short Guide. INDG281 Rev1 2001.Sudbury: HSE Books.

[14]. Health and Safety. (2001). Executive. Tackling Work-related Stress: A Guide for Employees. INDG341.Sudbury: HSE Books,

[15]. IvancevichM.J.,\& Donnelly H. J. (1975). Relation of Organizational Structure to Job Satisfaction, Anxiety-Stress, and Performance.Administrative Science Quarterly, Vol. 20, No. 2 , pp. 272-280.

[16]. Jamal M. (1984). Job Stress and job Performance controversy: an empirical assessment in two countries. Organizational Behavior and Human Performance, 33:1-21.

[17]. Kahn, R. L., Wolfe, D. M., Quinn, R. P., Snoek, J. D., \& Rosenthal, R. A. (1964). Organizational stress: Studies in role conflict and ambiguity. New York: Wiley

[18]. Kasl, S.V. (1973). Mental Health and the Work Environment. Journal of Occupational Medicine, Vol 15, pp. 509-518.

[19]. Lawrence, P., \&Lorsch, J. (1967). Organization and Environment: Managing Differentiation and Integration.Harvard University Press, Cambridge, Massachusetts.

[20]. Margolis, B.L., Kroes, W.H., \& Quinn, R.P. (1974). Job Stress: An Unlisted Occupational Hazard. Journal of Occupational Medicine, Vol, pp. 659-661.

[21]. McCubbin, H. I., \&Figley, C. R. (Eds.). (1983). Coping with normative transitions (Vol. 1). New York: Brunner/ Mazel.

[22]. Pincherle, G. (1972). Assessment of the Relation-ship Between Stress and Work Performance. Proceeding of the Royal Society of Medicine, Vol, pp. 321-324.

[23]. Rose M. (2003). Good Deal, Bad Deal? Job Satisfaction in Occupations.Work Employment Society, $17 ; 503$.

[24]. Stamper L.C.,\&Johlke C.M. (2003). The Impact ofPerceived Organizational Support on the Relationship Between Boundary Spanner Role Stress and Work Outcomes. Journal of Management, 29; 569.

[25]. Coleman J.C. 1976. Abnormal Psychology and Modern Life(Indian reprint), Taraporewalla, Bombay.

[26]. Beehr, Terry A. (1995), Psychological Stress in the Workplace,London and New York.

[27]. Beehr, T.A. \& Newman, J.E.,1978. "Job Stress, Employee Health and Organizational Effectiveness: A Facet Analysis, Model and Literature Review", Personnel Psychology, 31,pp.665-669.

[28]. Beehr, T.A., Walsh, J.T., \& Taber, T.D. 1976. "Perceived situational moderators of the relationship between subjective role ambiguity and role strain', Journal of Applied Psychology,61, pp.35-40.

[29]. Alexandros-Stamatios G. A., Matilyn J.D., and Cary L.C., 2003. "Occupational Stress, Job satisfaction, and health state in male and female junior hospital doctors in Greece", Journal of Managerial Psychology, 18(6), pp. 592-621.

[30]. Kahn, R.L., \& Quinn, R.P. 1970. Role stress: A framework for analysis, In A. McLean (Ed.), Occupational mental health, New York: Wiley.

[31]. Sarantakos, S. 1996. Modern Families, South Yarra: MacMillan Education Australis Pty Ltd.

[32]. Russo, J., \&Vitaliano, P. 1995. "Life events as correlates of burden in spouse caregivers of persons with Alzheimers disease", Experimental Ageing Research, 21, pp.273-294. 
[33]. Lasky, R.G, 1995. Occupational stress: a disability management perspective. In D.E. Shrey\& M. Lacerete (Eds.). Principles and Practices of Disability Management in Industry, pp.370-409.

[34]. Wilkes, L., Beale, B., Hall, E., Rees, E., Watts, B., \&Denne, C. 1998. "Community nurses' descriptions of stress when caring in the home", International Journal of Palliative Nursing,4 (1).

[35]. Al-Aameri A.S., 2003. "Source of job stress for nurses in public hospitals", Saudi Medical Journal,24(11), pp.1183-1187.

[36]. Chan, K.B., Lai, G., Ko, Y.C. \&Boey K.W., 2000. "Work stress among six professional groups: the Singapore experience", Social Science Medicine, 50(10), pp.1415-1432.

[37]. Townley, G. 2000. "Long hours culture causing economy to suffer", Management Accounting,78 (6), pp.3-5.

[38]. Cooper, C.L., 1991. Stress in organizations. In M. Smith (Ed.). AnalysingOrganisational Behaviour.London: MacMillan.

[39]. Cooper, C., U. Rout and B. Faragher. 1989. "Mental Health, Job Satisfaction, and Job Stress Among General Practitioners", B Medical Journal, 298, pp366-370.

[40]. Cordes, C.L., and Dougherty, T.W. 1993. "A review and integration of research on job burnout”, Academy of Mana gement Review, 18 , pp.621-656.

[41]. Dyer, S., \&Quine, L. 1998. "Predictors of job satisfaction and burnout among the direct care staff of a community learning disability service", Journal of Applied Research in Intellectual Disabilities, 11 (4), pp.320-332.

[42]. Ursprung, A.W. 1986. "Incidence and correlates ofburnout in residential service settings", Rehabilitation Counselling Bulletin, 29, pp.225-239.

[43]. Jackson, S.E., \& Schuler, R.S. 1985. "A meta-analysis and conceptual critique of research on role ambiguity and role conflict in work settings", Organizational Behavior and Human Decision Processes, 36, pp.16-78.

[44]. Muchinsky, P. 1997. Psychology applied to work: An introduction to industrial and organizational psychology(5th Ed.). Pacific Grove, CA: Brookes/Cole Publishers.

[45]. Kahn, R.L., Wolf, D.M., Quinn, R.P., Snoek, J.D., Rosenthal, R.A. (1964), Occupational stress: Studies in role conflict and ambiguity, New York: Wiley

[46]. Karasek, R.A. (1979), "Job demands, job decision latitude, and mental strain: Implications for job redesign", Administrative Science Quarterly, Vol. 24 No 2, pp.285-308

[47]. Ganster, D.C., Schaubroeck, J. (1991), "Work stress and employee health”, Journal of Management, Vol.17 No 2, pp.235-271.

[48]. Siegrist, J. (1996), "Adverse health effects of high effort-low reward conditions", Journal of Occupational Health Psychology, Vol. 1 No 1 , pp. $27-41$.

[49]. Edwards, J.R., Cooper, C.L. (1988), "The impacts of positive psychological states on physical health: a review and theoretical framework", Social Science and Medicine, Vol. 27 No 12, pp.1447-1459.

[50]. Cummings, T.G., Cooper, C.L. (1998), "A cybernetic theory of organizational stress", in Cooper, C.L. (Eds), Theories of Organizational Stress, Oxford University Press, New York, NY, pp.101-121.

[51]. Spector, P.E. (1998), A control theory of the job stress process, in Cooper, C.L. (Eds), Theories of Organizational Stress, Oxford University Press, New York, NY, pp.153-169.

[52]. Hobfoll, S.E. (1989), "Conservation of resources: A new attempt at conceptualizing stress", American Psychologist, Vol. 44 No 3, pp.513-524.

[53]. Qureshi M Tahir\&RamayI.Mohammad (2006). 'Impact of Human Resource Management Practices on Organizational Performance in Pakistan'. Muhammad Ali Jinnah University Islamabad.

[54]. Bartlett, C. A., \&Ghoshal, S. (1995). Changing the role of top management: beyond systems to people. Long Range Planning, 28(4), 126-126.

[55]. Armstrong, M., \& Baron, A. (2000). Performance management. Human resource management, 69.

[56]. Summers J, Hyman J (2005). 'Employee Participation and Company Performance'. Joseph 